\title{
EFFECT OF DIETARY FIBER ON PERFORMANCE AND DIGESTIBILITY OF NUTRIENTS FOR GROWING PEKIN DUCKS
}

\author{
S. A. Abd El- Latif
}

\section{Department of Animal Production, Faculty of Agriculture, Minia University}

\section{SUMMARY}

One hundred forty four one-day old Pekin ducks were used in this study to evaluate the utilization of dietary fiber ( $4,7,9$, and $12 \%$ crude fiber) by growing Pekin ducks. Saw dust was used as the main source of crude fiber in this experiment. The birds were divided equally into 4 groups containing 36 birds each. Each group contained 3 replicates of 12 birds. All diets were iso-caloric and isonitrogenous either during starting or growing periods. All birds were fed control diet from 0 to 2 weeks of age. The dietary treatments started from 2 to 8 weeks of age. At the end of the experiment, 3 birds from each treatment were sacrificed, after $12 \mathrm{hrs}$. fasting, to measure some carcass characteristics. Also 5 birds from each treatment were used in a digestion trial. Body weight and feed intake were recorded biweekly and feed efficiency values were calculated. The digestibility coefficients of nutrients were determined and calculated.

Body weight and body gain were not significantly affected by feeding Pekin ducks on crude fiber (CF) levels up to $12 \%$, during the entire tested period ( 2 to 8 weeks of age). While, during the period from 4 to 6 weeks of age, the highest level of $\mathrm{CF}(12 \%)$ recorded the lowest $(\mathrm{P}<0.05)$ body gain as compared with other dietary fiber treatments. The highest $(\mathrm{P}<0.05)$ feed intake was recorded when birds fed $7 \% \mathrm{CF}$. The best $(\mathrm{P}<0.05)$ feed efficiency values were noticed when birds fed 4 or $9 \% \mathrm{CF}$ compared with other dietary treatments during the entire period ( 2 to 8 weeks).

Birds fed on $9 \% \mathrm{CF}$ level recorded the best $(\mathrm{P}<0.05)$ dressing percent compared with the control diet. Edible and offals weight or their proportions were not affected by feeding Pekin ducks on tested diets.

Increasing $C F$ level up till $12 \%$ in the diet, improved $(P<0.01)$ the crude fiber $(C F)$ digestibility. The greatest value of $\mathrm{CF}$ digestibility was noticed when birds fed diet containing $9 \% \mathrm{CF}$. The control diet $\left({ }^{4} \% \mathrm{CF}\right)$ recorded the best $(\mathrm{P}<0.05)$ organic matter $(\mathrm{OM})$, crude protein $(\mathrm{CP})$, ether extract $(\mathrm{EE})$ and nitrogen free extract (NFE) digestibility of nutrients compared with other treatments.

The feeding cost of $1 \mathrm{~kg}$ weight gain reduced by $3.59 \%$ when birds fed $9 \% \mathrm{CF}$. Pekin ducklings could tolerate up till $12 \%$ in their diets without adverse effects on performance and feed utilization.

\section{Keywords: Saw dust, fiber, ducks, performance, digestibility}

\section{INTRODUCTION}

Feed cost comprises the major part of the running cost, due to the high prices of the traditional ingredients used. Ducks can tolerate higher percentage of fiber in their diets, which can lower the feeding cost, especially when the fiber sources are locally available with low price (Mutzar et al., 1977; Schubert et al., 1982; Kamar et al.,1989 and Farahat et al., 1998).

Although fiber is resistant to degradation by digestive enzymes secreted by certain organs of the chick, it can be degraded to oligosaccharides and monosaccharides by enzymes produced by microorganisms which inhabit the gastrointestinal tract. The sugar monomers are then fermented by bacteria to volatile fatty acids which serve as energy sources (Hungate, 1966; Kass et al., 1980). In Poultry, fiber fermentation apparently occurs in the ceca (Thornburn and Willox, 1965), crop (Bayer et al., 1978) and lower gastrointestinal tract (Annison et al., 1968).

Utilization of dietary fiber by ducks depends on so many factors, such as; the level of CF in the diet (Farahat et al., 1998), source of the CF (Soliman et al.,1987 and Hong et al., 1992), bread (Schubert et al., 1982), and age and sex of birds ( Kamar et al.,1989). Scott and Forbes (1958) noted that dietary fiber improved performance of chicks by simply narrowing the protein:calorie ratio, thus causing the chicks to eat more of the most limiting amino acids to meet its energy needs.

A study by Schubert et al. (1982), suggested that Mouscovy and Pekin ducks were better able to digest organic matter and crude fiber than laying hens. Accordingly, the metabolizable energy content of some fibrous ingredients (oats and rye) could be higher for ducks than for chickens because of the high fiber content of these cereal grains. Consequently, oats and rye could be used in duck rations when economic conditions allow. 
The present study was conducted to evaluate the tolerance of growing Pekin ducks for the utilization of dietary crude fiber $(4,7,9$, and $12 \%$ CF) and to investigate their effects on growth performance, carcass characteristics, and nutrients digestibility coefficients.

\section{MATERIALS AND METHODS}

One hundred forty four unsexed growing Pekin ducks one day old, were divided into 4 groups (36 birds, each) according to CF level. Each group contained 3 replicates of 12 birds. Birds were maintained in electrically heated floor pens housed in light and temperature controlled rooms. Birds were given free access to water and food.

The starter and control grower diets were formulated to contain adequate levels of nutrients for ducks as recommended by the National Research Council (NRC, 1994). Three additional diets were obtained using saw dust $(5,10$, and $15 \%$ ), as an ingredient in the diets to increase the CF level to be 7 , 9 , and $12 \%$. The control diet contained $4 \% \mathrm{CF}$ and was without saw dust addition. The diet formulas were adjusted to be iso-caloric and iso-nitrogenous. All birds were fed the control diet (starter) from 0 to 2 weeks of age. From 2 to 8 weeks of age the birds were fed on the tested $(4,7,9$, and $12 \% \mathrm{CF})$ diets. Composition of the control diets (starter and grower) are shown in Table 1.

Table 1. Composition and chemical analysis of the experimental diets

\begin{tabular}{|c|c|c|c|c|c|}
\hline \multirow[t]{2}{*}{ Ingredients: } & \multirow[t]{2}{*}{$\begin{array}{l}\text { Starting diet } \\
(0-2 \text { weeks })\end{array}$} & \multicolumn{4}{|c|}{$\begin{array}{l}\text { growing diet ( } 2-8 \text { weeks) } \\
\text {--Treatments ( fiber levels)--.- }\end{array}$} \\
\hline & & $4 \%$ & $7 \%$ & $9 \%$ & $12 \%$ \\
\hline Corn, ground yellow & 60.25 & 66.75 & 62.25 & 57.75 & 51.75 \\
\hline Wheat bran & 7.00 & 12.5 & 12.00 & 9.00 & 6.00 \\
\hline Soybean meal, dehulled $(44 \% \mathrm{CP})$ & 22.50 & 10.50 & 10.50 & 12.00 & 14.00 \\
\hline Broiler concentrate $(52 \%)$ & 10.00 & 10.00 & 10.00 & 10.00 & 10.00 \\
\hline Saw dust" & 0.00 & 0.00 & 5.00 & 10.00 & 15.00 \\
\hline Poultry fat & 0.00 & 0.00 & 0.00 & 1.00 & 3.00 \\
\hline Vitamins \& Minerals mixture & 0.25 & 0.25 & 0.25 & 0.25 & 0.25 \\
\hline \multicolumn{6}{|l|}{ Proximate analysis } \\
\hline Crude protein, $\%$ & 21.73 & 17.76 & 17.39 & 17.30 & 17.79 \\
\hline Crude fiber, $\%$ & 3.97 & 3.94 & 6.85 & 8.94 & 11.87 \\
\hline \multicolumn{6}{|l|}{ Calculated values } \\
\hline Metabolizable energy (Kcal / kg) & 2873 & 2889 & 2858 & 2894 & .2859 \\
\hline Calcium, \% & 0.980 & 0.925 & 0.926 & 0.928 & 0.928 \\
\hline Av. Phosphorus, \% & 0.546 & 0.523 & 0.522 & 0.521 & 0.521 \\
\hline Methionine cystine, \% & 0.741 & 0.614 & 0.612 & 0.610 & 0.609 \\
\hline Lysine, $\%$ & 1.620 & 1.408 & 1.406 & 1.402 & 1.402 \\
\hline
\end{tabular}

* Saw dust is the main source of the crude fiber

** Each $2.5 \mathrm{~kg}$ of vitamins and minerals mixture contain: 12000,000 IU vitamin A acetate; 2000,000 IU vitamin D3; $10.000 \mathrm{mg}$ vitamin $\mathrm{E}$ acetate; $2000 \mathrm{mg}$ vitamin $\mathrm{K} 3 ; 100 \mathrm{mg}$ vitamin $\mathrm{B} ; 4000 \mathrm{mg}$ vitamin $\mathrm{B} 2 ; 1500 \mathrm{mg}$ vitamin B6; $10 \mathrm{mg}$ vitamin B $12 ; 10.000 \mathrm{mg}$ Pantothenic acid; $20.000 \mathrm{mg}$ Nicotenic acid; $1000 \mathrm{mg}$ Folic acid; $50 \mathrm{mg}$ Biotin; 500,000 mg Choline; $10.000 \mathrm{mg}$ Copper; $1000 \mathrm{mg}$ lodine; 30,00 mg Iron; 55,000 mg Manganese; 55,000 $\mathrm{mg}$ Zinc, and $100 \mathrm{mg}$ Selenium.

Body weight and feed intake were measured for birds biweekly and feed efficiency values (gain/ feed) were calculated.

At the end of the experiment, 3 drakes from each treatment were randomly taken, derived from feed but not water for about 12 hrs and slaughtered. After bleeding out, the birds were scalded, plucked with electrical cycomatic picker and eviscerated. Some carcass characteristics were measured. Another five male birds from each treatment were used for a digestion experiment to evaluate nutrient digestibility of the tested diets. The birds were housed individually and fed the tested diets. After 3 days acclimatization period, the collection period continued for 6 days during which feed intake was measured and excreta output was collected daily, oven dried $\left(70^{\circ} \mathrm{C}\right.$ for $\left.24 \mathrm{hrs}\right)$, weighed and ground. The representative samples were used for analysis. The chemical analysis of diets and excreta for DM, EE, CP, CF, and ash were conducted according to A.O.A.C. (1984). For calculating CP digestibility, the fecal protein was determined according to Ekman et al. (1949). To obtain urinary organic matter, the figure of urinary nitrogen was multiplied by the factor 2.62 . This factor was computed by Galal (1968) as shown in Sturkie (1965). 
ANOVA and LSD procedures were performed as outlined by Snedecor and Cochran (1980).

\section{RESULTS AND DISCUSSION}

The effects of dietary treatments on body weight, body gain, feed intake, and feed efficiency (gain/feed) are shown in Table 2. It was observed that increasing CF levels up to $12 \%$, had no significant effect on body weight and body gain at the end of the experiment ( 8 weeks old). During the period ( 4 to 6 weeks) of the experiment, birds fed diet contained $7 \% \mathrm{CF}$ recorded the highest $(\mathrm{P}<0.05)$ values of body gain compared with other higher CF treatments. These results agree with Kamar et al.(1989) who reported that ducks given the diet containing $7.2 \% \mathrm{CF}$, recorded the highest body gain compared with other groups given $10 \% \mathrm{CF}$ diet. They reported that older ducks may be capable of utilizing crude fiber than young ducks. The performance of Arbor Acres broiler chicks from 2 to 8 weeks of age fed diets varying in dietary fiber levels $(3,5,7$, and $9 \% \mathrm{CF}$ ) was measured by Abbas, (1992), who showed that, the chicks could tolerate up to $9 \% \mathrm{CF}$ in their diets. some depression in body weight gain, feed intake, and carcass characteristics was observed with $9 \% \mathrm{CF}$, while, $7 \% \mathrm{CF}$ level had no adverse effect on all parameters under study.

In general, body gain was reduced during the entire period ( 2 to 8 weeks of age), when CF levels were increased up to $12 \%$. This depression may be due to the reduction in $\mathrm{CP}$ and EE digestibilities; from 83.28 to $69.49 \%$ and 59.38 and $32.83 \%$ respectively (Table 4 ).

Table 2. Effect of dietary crude fiber on body weight, body gain, feed intake, and feed efficiency (gain/feed) of growing Pekin ducks

\begin{tabular}{|c|c|c|c|c|c|c|}
\hline \multirow[t]{2}{*}{ Age, weeks } & \multirow{2}{*}{$\begin{array}{l}\text { Age, } \\
\text { weeks }\end{array}$} & \multicolumn{3}{|c|}{ Treatments (fiber levels) } & \multirow[b]{2}{*}{$12 \%$} & \multirow[b]{2}{*}{ Sig. } \\
\hline & & $4 \%$ & $7 \%$ & $9 \%$ & & \\
\hline \multirow[t]{4}{*}{ Body weight(gm) } & 2 & $275.0 \pm 31$ & $224.1 \pm 34$ & $232.4 \pm 29$ & $234.2 \pm 37$ & ns \\
\hline & 4 & $840.0 \pm 21$ & $765.0 \pm 34$ & $802.7 \pm 40$ & $767.0 \pm 50$ & ns \\
\hline & 6 & $1503.3 \pm 91$ & $1461.7 \pm 56$ & $1485.0 \pm 74$ & $1381.7 \pm 77$ & ns \\
\hline & 8 & $2415 \pm 100$ & $2370.0 \pm 90$ & $2433.3 \pm 99$ & $2315.0 \pm 43$ & ns \\
\hline \multirow[t]{4}{*}{ Body gain $(\mathrm{gm})$} & 2 to 4 & $565.0 \pm 22$ & $540.9 \pm 19$ & $570.3 \pm 23$ & $532.8 \pm 24$ & ns \\
\hline & 4 to 6 & $663.3^{\mathrm{a}} \pm 53$ & $696.7^{\mathrm{a}} \pm 22$ & $682.3^{\mathrm{a}} \pm 40$ & $614.7^{b} \pm 36$ & $*$ \\
\hline & 6 to 8 & $911.7 \pm 13$ & $908.3 \pm 39$ & $948.3 \pm 99$ & $933.3 \pm 34$ & ns \\
\hline & 2 to 8 & $2140.0 \pm 83$ & $2145.9 \pm 96$ & $2200.9 \pm 99$ & $2080.8 \pm 82$ & ns \\
\hline \multirow[t]{4}{*}{ Feed intake(gm) } & 2 to 4 & $1918.3 \pm 150$ & $2283.7 \pm 129$ & $2171.7 \pm 147$ & $1933.3 \pm 59$ & ns \\
\hline & 4 to 6 & $2315.0 \pm 50$ & $2376.7 \pm 160$ & $2408.3 \pm 75$ & $2503.3 \pm 76$ & ns \\
\hline & 6 to 8 & $3019.0 \pm 75$ & $3037.6 \pm 89$ & $3001.0 \pm 78$ & $3062.4 \pm 56$ & ns \\
\hline & 2 to 8 & $7252.3^{b} \pm 125$ & $7697.9^{\mathrm{a}} \pm 136$ & $7581.0^{\mathrm{a}} \pm 160$ & $7499.1^{a} \pm 130$ & $*$ \\
\hline \multirow{4}{*}{$\begin{array}{l}\text { Feed efficiency } \\
\text { (gain/feed) }\end{array}$} & 2 to 4 & $0.294 \pm 0.01$ & $0.236 \pm 0.03$ & $0.262 \pm 0.0$ & $0.275 \pm 0.0$ & ns \\
\hline & 4 to 6 & $0.286 \pm 0.01$ & $0.293 \pm 0.03$ & $0.283 \pm 0.0$ & $0.245 \pm 0.0$ & ns \\
\hline & 6 to 8 & $0.302 \pm 0.00$ & $0.299 \pm 0.03$ & $0.315 \pm 0.0$ & $0.304 \pm 0.0$ & ns \\
\hline & 2 to 8 & $0.295^{\mathrm{a}} \pm 0.06$ & $0.278^{\mathrm{b}} \pm 0.1$ & $0.290^{\mathrm{a}} \pm 0.1$ & $0.277^{\mathrm{b}} \pm 0.0$ & $*$ \\
\hline
\end{tabular}

${ }^{\mathrm{a}}$ and ${ }^{\mathrm{b}}$ data in the same row followed by unlike letters differ significantly.

$*(\mathrm{P}<0.05)$ significant level, $\quad \mathrm{ns}=$ Not significant level \pm S.E

During the entire period ( 2 to 8 weeks of age), it was observed that the feed intake improved $(\mathrm{P}<0.05)$ in dietary $\mathrm{CF}$ compared with the control diet, reaching to greatest value at $9 \% \mathrm{CF}$ level in the diet. This increase in feed intake without respective increase in body gain, for groups fed 7 or $12 \% \mathrm{CF}$, resulted in depression $(\mathrm{P}<0.05)$ in feed efficiency $(\mathrm{Gain} / \mathrm{feed})$. The best $(\mathrm{P}<0.05)$ feed effeiciency was noticed when birds fed control or $9 \% \mathrm{CF}$ diets. No significant effects were observed on either feed intake or feed efficiency during the periods ( 2 to 4,4 to 6 or 6 to 8 weeks of age) of the experiment. The improvement in feed intake may be due to, that the fiber decreases the digestibility of metabolizable energy of the diet and more food was needed to satisfy physiological requirements (Savory and Gentle, 1976). Scott and Forbes (1958) found that increasing dietary fiber for chicks, causing the chicks to eat more of the most limiting amino acids to meet its energy needs. So the feed efficiency depressed.

Reported in Table 3, the effect of dietary treatments on some carcass characteristics. It is clear that, there were no significant differences in carcass weight, edible or offal part weights among the dietary treatments. This result was in harmony with the results of body gain, which show that ducks, given 
dietary fiber had no significant differences among treatments. The best $(\mathrm{P}<0.05)$ values of dressing percentage were recorded for groups fed either 7 or $9 \%$ dietary fiber compared with other dietary treatments. No significant differences were observed in the proportions of edible or offal part weights. Kamar et al. (1989) reported that, the dressing percentages were significantly different between crude fiber levels. The length of the alimentary canal was similar for the of 7 or $10 \%$ CF. Osman et al. (1996) found that carcass weight and dressing percentage were not deteriorated by feeding Pekin ducklings on non-conventional diet $(5.79 \% \mathrm{CF})$ compared with conventional $\operatorname{diet}(3.41 \% \mathrm{CF})$, while liver, gizzard, the total edible giblets percentages, the relative digestive tract, and cecum length absolutely and relatively, were increased when duckling were fed on non-conventional diet. The increase in relative digestive tract weight could be attributed to the increase in gizzard weight and cecum length which may be an adaptation of the bird to consume and digest the fiberous of nonconventional diet.

Table 3. Effect of dietary crude fiber on some carcass characteristics of growing Pekin ducks

\begin{tabular}{lccccc}
\hline Items & \multicolumn{5}{c}{ Treatments (crude fiber levels) } \\
& $4 \%$ & $7 \%$ & $9 \%$ & $12 \%$ & Sig. \\
\hline & & & & & \\
Live weight, gm & $2136.3 \pm 18.3$ & $2100.0 \pm 28.9$ & $2046.7 \pm 27.3$ & $2083.7 \pm 43.8$ & $\mathrm{~ns}$ \\
Carcass, gm & $1420.0 \pm 17.3$ & $1471.7 \pm 18.6$ & $1436.7 \pm 31.8$ & $1413.3 \pm 6.7$ & $\mathrm{~ns}$ \\
Edible $^{1}$, gm & $318.3 \pm 25.8$ & $306.7 \pm 17.6$ & $309.80 \pm 6.7$ & $300.0 \pm 45.1$ & $\mathrm{~ns}$ \\
Offals $^{2}$, gm & $588.3 \pm 36.4$ & $526.7 \pm 23.3$ & $516.7 \pm 8.8$ & $563.3 \pm 17.6$ & $\mathrm{~ns}$ \\
Dressing percent, & $66.8^{\mathrm{a}} \pm 0.92$ & $70.1^{\mathrm{b}} \pm 0.3$ & $70.2^{\mathrm{b}} \pm 0.6$ & $67.8^{\mathrm{a}} \pm 1.06$ & $*$ \\
Edible, \% & $14.9 \pm 1.34$ & $14.6 \pm 0.63$ & $15.1 \pm 0.13$ & $14.4 \pm 0.68$ & $\mathrm{~ns}$ \\
Offals, \% & $27.5 \pm 1.36$ & $25.1 \pm 0.76$ & $25.3 \pm 0.21$ & $27.0 \pm 0.28$ & $\mathrm{~ns}$ \\
\hline
\end{tabular}

${ }^{\text {a.b }}$ and ${ }^{\mathrm{c}}$ data in the same row followed by unlike letters differ significantly.

${ }^{1}$ Edible $=$ liver and gizzard ${ }^{2}$ Offals $=\mathrm{GI}+$ head and legs

* $(\mathrm{P}<0.05)$ significant level $\quad \mathrm{ns}=$ Not significant level $\quad \pm$ S.E

The effect of dietary crude fiber on the digestibility coefficients of nutrients for growing Pekin ducks are shown in Table 4. A significant $(\mathrm{P}<0.01)$ depression was observed in the digestibility coefficients of OM, CP, EE, and NFE $(\mathrm{P}<0.05)$ when, the $\mathrm{CF}$ level increased in the diet more than $4 \%$. The digestibility of $\mathrm{CF}$ improved $(\mathrm{P}<0.05)$ by increasing $\mathrm{CF}$ level in the diet, reaching to maximum level at $9 \% \mathrm{CF}$.

Table 4. Effect of dietary crude fiber on the digestibility coefficients for growing Pekin ducks

\begin{tabular}{|c|c|c|c|c|c|}
\hline \multirow[b]{2}{*}{ Items } & \multicolumn{5}{|c|}{-Treatments ( Fiber levels ) } \\
\hline & $4 \%$ & $7 \%$ & $9 \%$ & $12 \%$ & Sig. \\
\hline Dry matter & $77.44 a \pm 0.36$ & $70.02 \mathrm{ab} \pm 1.48$ & $59.21 \mathrm{~b} \pm 10.01$ & $65.85 \mathrm{ab} \pm 0.27$ & * \\
\hline Organic matter & $78.34 \mathrm{a} \pm 0.23$ & $71.39 \mathrm{~b} \pm 1.63$ & $70.24 b \pm 0.35$ & $66.88 c \pm 0.25$ & ** \\
\hline Crude protein & $83.28 \mathrm{a} \pm 0.85$ & $74.86 \mathrm{~b} \pm 1.15$ & $69.31 \mathrm{c} \pm 0.30$ & $69.49 \mathrm{c} \pm 1.14$ & $* *$ \\
\hline Crude fiber & $25.23 \mathrm{a} \pm 0.63$ & $26.12 \mathrm{a}+3.23$ & $39.48 \mathrm{~b} \pm 4.47$ & $30.62 \mathrm{a} \pm 0.64$ & ** \\
\hline Ether extract & $59.38 \mathrm{a} \pm 0.99$ & $40.75 b \pm 1.18$ & $28.38 \mathrm{c} \pm 23.1$ & $32.83 c \pm 0.45$ & $* *$ \\
\hline Nitrogen free extract & $84.59 a \pm 0.06$ & $81.56 \mathrm{~b} \pm 1.30$ & $83.63 \mathrm{ab} \pm 0.60$ & $81.98 \mathrm{ab} \pm 0.59$ & $*$ \\
\hline
\end{tabular}

Kamar et al. (1989) reported that, the digestibility of almost all nutrients are higher for the control diet than diets containing $10 \% \mathrm{CF}$, from different sources. Schubert et al.(1982), suggested that Muscovy and Pekin ducks were better able to digest organic matter and crude fiber than laying hens. Kamar et al. (1989) reported that, the digestibility of almost all nutrients are higher for the control diet than diets containing $10 \% \mathrm{CF}$, from different sources. Schubert et al.(1982), suggested that Muscovy and Pekin ducks were better able to digest organic matter and crude fiber than laying hens.

Calculations of the economical study were carried out according to values shown in Table 5 . The lowest diet cost was noticed in the diet which included 12\% (15\% saw dust) among the other experimental diets. It is clear that the cost of diet reduced by increasing fiber level in the diet up to $12 \%$. The diet contains $9 \% \mathrm{CF}$ recorded the best values of net revenue and the percent of net revenue/feed cost. It can be seen that the feeding cost of $1 \mathrm{~kg}$ weight gain was reduced by $(2.169-2.091 /$ 
2.169) $\times 100=3.59 \%$ when birds fed $9 \%$ CF. This is in agreement with finding of Abd El-Latif (1987) who reported that dietary $14 \%$ CF (including $20 \%$ of broiler litter) reduced the dietary cost by $18.3 \%$ in growing rabbits.

Table 5. Effect of dietary crude fiber on the economical efficiency for growing Pekin ducks

\begin{tabular}{lcccc}
\hline Items & \multicolumn{4}{c}{ Treatments } \\
& $4 \%$ & $7 \%$ & $9 \%$ & $12 \%$ \\
\hline & & & & \\
& 0.640 & 0.621 & 0.607 & 0.598 \\
Cost of 1 kg feed (a), L.E* & 3.389 & 3.587 & 3.445 & 3.604 \\
Feed /gain ratio (b) & 2.169 & 2.227 & 2.091 & 2.155 \\
Feed cost of 1 kg weight gain (a.b), L.E & 6.00 & 6.00 & 6.00 & 6.00 \\
Market price of 1 kg live weight (c), L.E & 3.831 & 3.773 & 3.909 & 3.845 \\
Net revenue [c-(a.b)], L.E & 176.63 & 169.42 & 186.93 & 178.42 \\
\hline Percent of net revenue/ feeding cost & &
\end{tabular}

* Cost of one kilogram feed during year 2000 by Egyptian pound (LE)

In conclusion, adding $15 \%$ saw dust to the growing Pekin ducklings diet, had no adverse effect on performance and feed utilization. In other meaning, Ducks could tolerate up to $12 \% \mathrm{CF}$ in their diets.

\section{REFERENCES}

Abd El-Latif, S. A., 1987. Growth rate, digestibility coefficients and carcass quality of rabbits fed different crude protein and crude fiber levels in their diets. M. Sc. Thesis, Fac Agric., Minia Univ., Egypt.

A. O. A. C. 1984. Association of Official Analytical Chemists. Ed. A. O. A. C., Inc., 1111 North Nineteenth Street, Suite 210, Arlington, Virginia 22209, USA

Abbas, A. M. 1992. Effect of dietary fiber on broiler performance. Journal of Agricultural Sci. 17(10) 3165-3173.

Annison, E. T., K. J., Hill, and R. Kenworthy, 1968. Volatile fatty acids in digestive tract of the fowl. Br. J. Nutr. 22:207-216.

Bayer, R. C., W. H. Hoover, and F. V. Muir, 1978. Dietary fiber and meal feeding influence on broiler growth and crop fermentation. Poultry Sci. 57:1456-1459.

Ekman, P., H. Emanuelson and A. Fransson, 1949. Investigations concerning the digestibility of protein in poultry. Annals Royal Agric. College of Seweden 16:749-777.

Farahat, A., L. Nirmand, ER. Chavez, SP. Touchburn 1998. Nutrient digestibility in food waste ingredients for Pekin and Muscovy ducks. Poultry Sci. 77(9): 1371-1376.

Galal, A. Gh, 1968. A study of some carbohydrate components of poultry feeds and their relation to the feeding value with reference to legnin fraction. Ph.D. Thesis, Fac. Agric., Cairo Univ.

Hungate, R, E. 1966. The rumen and its microbes. Academic Press, New York, NY.

Hong, Lu. H., Jy. Huang, JK., and Hq. Li, 1992. Research on methods for utilizing the filtered-off waste from sugar-producing areas of China. Ziranziyuan. 1, 71-75.

Kass, M. L., P. J. Van Soest, and W. G., Pond 1980 Utilization of dietary fiber from alfalfa by growing swine. II. Volatile fatty acid concentrations in and disappearance from the gastrointestinal tract. J. Anim. Sci. 50:192-197.

Kamar, G. A. R., H. M., Karima, S. Mahamed,S. M. T., El Tantawy, and Nagwa Maghraby 1989. Effect of dietary 10 percent crude fiber from different sources on feeding Muscovy ducks. Anaals Agric. Sci., Fac. Agric., Ain Shams., Cairo. Egypt, 34 (2), 1045-1056.

Mutzar, A. S., S. J., Slinger, and J. H. Burton 1977. Metabolizable energy content of fresh plants in chickens and ducks. Poultry Sci. 56: 1893-1899.

National Research Council 1994: Nutrient Requirements of Poultry. ed. Nat. Acad. Sci. 40:1234.

Osman, A. M. A., M. A. H. Soliman, S. A. Abd El-Latif 1996. Evaluation of non-conventional diet for growing pekin ducklins. Egypt. Poult. Sci. Vol.16(11)365-378.

Savory, G. J., and M. J. Gentle 1976. Changes in feed intake and gut size in Japanese quail in response manipulation of dietary fiber content. Br. Poultry Sci. 17:561-570.

Schubert, R. G. Richter, and K. Gruhn, 1982. Comparative investigation of the digestive performance of cairina, peking ducks and laying hens. Arch. Tierenaehr. 32: 531-537.

Scott, H. M., and R. M. Forbes, 1958. The argenine requirements of chicks in relation to diet composition. Poultry Sci. 37:1347-1349. 
Soliman, H. S., A. M. El- Serafy, M. El- Ashry, M. El-Sokkary, M. M. Shoukry and H. M. Khattab 1987. In situ and in vitro studies on the response of wheat straw, rice straw, corn cobs, and cotton stalks to sodium hydroxide treatments. J. Agric. Sci., Mansoura Univ., 12:750-758.

Sturkie. P. D. 1965. " Avian physiology " 2nd ed. Bailliere Tindall and Casselly, London.

Snedecor, G. W. and W. G. Cochran, 1980. Statistical Methods. 7 th ed.. The Iowa State University Press. Ames, Iowa.

Thornburn, C. C. and J. S. Willox 1965. The caeca of the domestic fowl and digestion of the crude fiber complex. II. Experiments in vivo with fistulated birds, and the artificial and isolated caecum in vitro. Br. Poultry Sci., 6:33-43. 